\title{
Feedback controlled laser system for safe and efficient reshaping of nasal cartilage
}

\author{
Emil Sobol, Alexander Sviridov, Natalia Vorobieva, Valery Svistushkin* \\ From 2nd Scientific Meeting of the Head and Neck Optical Diagnostics Society \\ San Francisco, CA, USA. 23-24 January 2010
}

In 1992, we identified laser-induced stress relaxation in cartilage. This led to the development of a new laser application in otolaryngology- head and neck surgery for the non-ablative reshaping of cartilage. Laser septochondrocorrection is non-invasive, bloodless, painless procedure which takes only 10 minutes to complete and can be performed in outpatient settings.

The efficacy and safety of this technology can be guarantied with the feed back control system measuring temperature and stress distribution in the course of laser treatment. The paper presents recent results of the research and clinical applications of the technology and equipment for laser reshaping of cartilage in the ENT. The new equipment LSC-701 (Arcuo Medical Inc., USA) for laser reshaping of nasal cartilage includes an Erbium doped glass fiber laser (1.56 micrometers in wavelength), special instrument and feedback control system which allow to correct laser settings in the course of laser treatment and to stop the laser when the procedure is completed. The laser technology and equipment are certificated by the Federal Service on Surveillance in Healthcare and Social Development of Russian Federation. The laser septocorrection using LSC-701 has been performed for 120 patients at the ENT Clinics of the Sechenov Medical Academy of Moscow and at the Vladimirskiy Research and Clinical Institute of Moscow Region (MONIKI). The positive results were obtained for 95 percent of the patients in two years follow up. No age limitation (for the patients from 12 until 68 years), no complications and negative secondary effects were observed.

Vladimirskiy Research and Clinical Institute of Moscow, Moscow, Russian Federation
Published: 29 October 2010

doi:10.1186/1758-3284-2-S1-017

Cite this article as: Sobol et al:: Feedback controlled laser system for safe and efficient reshaping of nasal cartilage. Head \& Neck Oncology 2010 2(Suppl 1):O17.
Submit your next manuscript to BioMed Central and take full advantage of:

- Convenient online submission

- Thorough peer review

- No space constraints or color figure charges

- Immediate publication on acceptance

- Inclusion in PubMed, CAS, Scopus and Google Scholar

- Research which is freely available for redistribution

Submit your manuscript at www.biomedcentral.com/submit
C Biomed Central 